
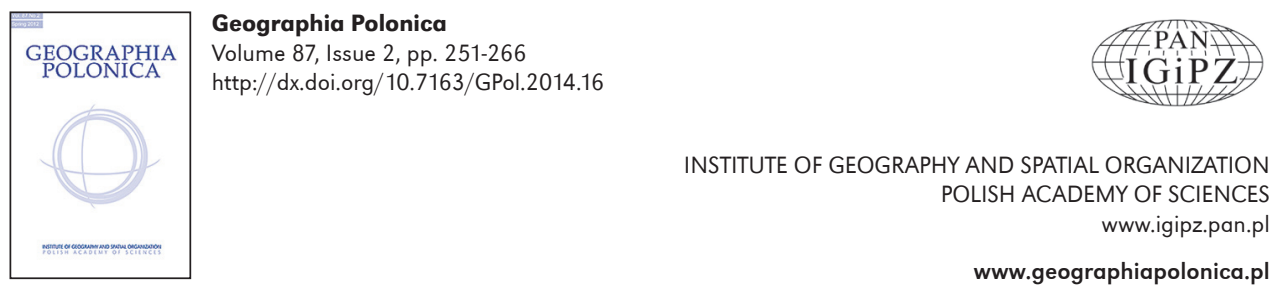

\title{
WILL GEOGRAPHY REMAIN GEOGRAPHY? PONDERING THE STATE OF GEOGRAPHY
}

\author{
Antoni Jackowski \\ President of the Polish Geographical Society \\ Jagiellonian University \\ Institute of Geography and Spatial Management \\ Gronostajowa 7, 30-387 Krakow: Poland \\ e-mail: antoni.jackowski@wp.pl
}

\begin{abstract}
For decades, we have been witnessing a gradual disintegration of geography. The issue was first flagged at the turn of the 19th century, but the process accelerated in the late 1960s. The term 'geography' has been increasingly replaced with other terms and one of the effects has been a diminishing status of geography in public awareness. Polish geographers attempted to address the problem as early as in the first decades of the 20th century, but these efforts, especially before 1939, remain obscure. Researchers continued their work even during the Second World War when they were often operating in extreme conditions. This scientific heritage has a potential to be used in contemporary work on a new view of geography at a time of increasing globalisation.
\end{abstract}

\section{Key words}

geography $\bullet$ Polish geography $・$ disintegration $\cdot$ history of geography $・$ Poland

For hardship does not spring from the soil, nor does trouble sprout from the ground. (Book of Job: 5.6 )

The research behind this paper was inspired by my lingering concern at the sight of the increasing disintegration of geography. The paper draws on a selection of events from the history of Polish geography, which should help the reader better understand the views of geography espoused by our geographic predecessors. Many years on, their messages are still relevant and fit well into the current debate about the essence of geography.

Let us for a while imagine geography as a grand old tree, the kind that depicts the genealogy of an ancient family. Going back through time, one can imagine that at some point, especially during the 20th century, branches begin to spread, some of them thin and fragile. They represent small specialised fields, many of which never reach maturity. 
The branching of the tree is a result of centuries of growth of geography. The four main boughs symbolise the four oldest disciplines: physical geography, regional geography, human geography and cartography. As they continued to grow, new categories emerged and the older ones, such as cartography, tended to split from the family tree entirely. There were a number of reasons for this effect to occur. For example, before the Second World War efforts were made in Poland to split economic geography from geography. The man behind this movement was Wiktor Ormicki, who wrote much about it although much of his work was never published (Jackowski 2011). Some young branches were artificially created under the pressure of external forces, including political. During communism, human geography in Central and Eastern Europe was forced to adapt to a Soviet model of geography. To communist decision makers the old human geography, with its achievements and rich tradition, reeked with 'bourgeois' ideas.

In Poland, two seminal geographic conferences, held at Osieczna ${ }^{1}$ (1955) and at Jabłonna² (1966), espoused this argumen-

\footnotetext{
1 Between 28 November and 1 December 1955, the Institute of Geography of the Polish Academy of Sciences together with the Ministry of Higher Education organised a seminal conference at Osieczna near Leszno. Its official title was "The Conference and Course of the Institute of Geography PAS and of the Ministry of Higher Education on the question of economic geography". Its proceedings would play a major role in the subsequent development of this field of geography. Sharp criticism was levelled at the international so-called 'bourgeois' geography, including the huge achievements of pre-war Polish geography, especially human geography. The conference adopted a 'branched' structure of economic geography, including its subdivision into the geography of population and settlement, geography of industry, geography of agriculture and geography of transport.

2 In 1966, a conference at Jabłonna dealt with the issues of methodology and theory in economic geography. This followup to the Osieczna conference was intended to review the practice of that conference and to set new avenues for research. At Jabłonna, the branched subdivision of economic geography adopted at Osieczna was further expanded. New fields were defined, including the geography of consumption, services and culture, as well as the political geography of the world. The debate focused around issues including:
}

tation and pronounced human geography obsolete. Instead, it was recommended that geography should adopt Marxist methodology, as used in the Soviet Union. A new subdivision of economic geography was adopted at Osieczna, including the splitting of regional geography into its economic and physical sections, and this was further expanded at Jabłonna. Luckily, these decisions were never fully implemented and while the breakdown of geography became a fact, the Marxist methodology has never become obligatory. On the contrary, Polish geographers found the theoretical and methodological studies of their western colleagues very appealing. Much later, as the political and socio-economic environment improved, another conference, at Rydzyna (1983), was convened to neutralise the effect of adverse processes set off in Polish geography at the Osieczna and Jabłonna conferences ${ }^{3}$. Since then, Polish geography has been reverting to human geography.

$$
\star \star \star
$$

Geography is one of a handful of disciplines that have their roots in antiquity. This is something to be proud of and we often need to remind ourselves that eminent classical thinkers built scholarly systems around geography. These thinkers include Eratosthenes ( $3 r d$ century BC), Strabo (1st century $A D)$ and Ptolemy ( 2 nd century AD).

Eratosthenes built the oldest system of geography known today. He laid it out in Geographika (3rd century BC) stating that the object of geography was to measure the Earth and its elements, determining the extent of the inhabited universe (ecumene),

(I) integration in economic geography, (II) quantitative methods, mathematical machines and their applcation in economic geography, (III) methodological and theoretical issues of an economic region, and (IV) the theory of economic geography.

3 The final of the trio of milestone conferences on the fundamentals of geography in Poland was held in Rydzyna from 27 to 30 June 1983. It had the title: "Fundamental methodological problems in the development of Polish geography" and aimed to identify the state of Polish geography in comparison to world geography, and to formulate its new development agenda. 
setting geographic coordinates, transferring the surface of Earth onto a plane using coordinates, drawing contours of lands, rivers and, ultimately, to draw maps of the ecumene. Eratosthenes was the first to attempt to combine mathematical geography, general physical knowledge and regional geography in a single discipline of knowledge. His contribution was to replace mythological elements with measurements and figures.

Strabo set out his system in Geographika hypomnemata (1st century AD) where he proposed that the object of geography was dualistic involving both the natural environment and humans. According to Strabo, geography was a detailed field with a regional and descriptive approach, limited to the ecumene and was an art.

The most extensive system of geography of the three was proposed by Claudius Ptolemy in Geographiké hyphegesis (2nd century AD). Ptolemy's geography concerned itself with determining the shape and dimensions of the Earth, identifying the geographic coordinates of objects on its surface and developing their cartographic presentation. Mapping was the objective of geography. As such, Ptolemy's geography represented a mathematical-naturalistic approach. It was a science whose purpose was to offer quantitative analysis, but it left out any investigation of the nature of geographic phenomena (Izmaiłow 2004).

These three systems outlined the object of this discipline and its future development. Are we to eliminate this from our geographic minds?

Subsequent generations of geographers built creatively on the achievements of the giants of antiquity, but it took many centuries until Bernhardus Varenius (17th century) and more importantly Alexander von Humboldt and Karl Ritter (19th century) would form entirely new geographic systems. The latter two proved crucial for the recognition of geography as a separate discipline. Humboldt's system of physical geography was based on empiricism and reasoning. It was introduced in his seminal book Kosmos
(1845-1858), which was published in Polish translation a few years after the German original. According to Humboldt, the objects of geographical research are causal relations between inorganic and organic nature, in which humans are partly included. He saw geography as a separate natural discipline. Ritter's system, on the other hand, was anthropocentric. In his Die Erdkunde im Verhältnis zur Natur und Geschichte des Menschen Ritter (1817-1859) postulated that it was the human who was the main focus of geography, which dealt with mutual influences between the natural environment and humans. His geography was descriptive, generalising, regionalist and it proposed a composite view of the Earth from an anthropocentric point of view. It was a separate discipline seeking to explain the history of humankind through changes in nature (Izmaiłow 2004).

The work of the two 19th century German scholars proved a breakthrough in the development of geography. It was sufficient to attract interest in this discipline and scholars of many countries began to build upon and enrich these systems. Their achievements became part of the canon of world geography and their names ought to remain in the memory of every geographer while their books should be regarded as classical and basic texts for their respective fields.

Polish scholars joined this search for a new theoretical and methodological paradigm at an early stage. Wincety Pol introduced Humboldt's and Ritter's new systems to Polish academia and established the first Polish geography department at the Jagiellonian University in 1849. Despite his rather meteoric academic career, as the Austrian authorities removed him from the University for his patriotic activity and closed the department in 1852, it provided the breakthrough necessary for Polish geography to turn into a modern discipline of knowledge. Franciszek Czerny-Schwarzenberg, who reactivated the defunct department in 1877, continued Pol's work, as did many others. These included Antoni Rehman (1840-1917), a geobotanist, 
traveller and geographer active in the Carpathian and Caucasus Mts., who opened the second Polish geography department in Lvov University (1882); Wacław Nałkowski (1851-1911), one of the world's first reformers of geography curricula in schools and the founder of modern Polish geography based on reasoning and direct observation; Eugeniusz Romer (1871-1954), founder of a major school of cartography and vice-president of the International Geographical Union (1931-1938 and 1945-1954).

This development led to the flourishing of Polish geography between the wars. A number of research centres emerged, including Krakow with such figures as Ludomir Sawicki (geomorphologist, human geographer), Jerzy Smoleński (geomorphologist, human and political geographer), Walenty Winid (human geographer); Lvov with Eugeniusz Romer (organiser of the famous school of cartography), Henryk Arctowski (meteorologist and climatologist, polar researcher); Warsaw with Stanisław Lencewicz (physical and regional geographer), Władysław Gorczyński (meteorologist and climatologist), Bogdan Zaborski (human geographer), Antoni Sujkowski (economic geographer); Poznań with Stanisław Pawłowski (geomorphologist, political and regional geographer), Stanisław Nowakowski (economic geographer); and Vilnius with Mieczysław Limanowski (geomorphologist, human geographer) and Kazimierz Jantzen (meteorologist and climatologist). Towards the end of the inter-war period though, a new wave of schools of geography began to emerge around such figures, as: Wiktor Ormicki (Krakow), August Zierhoffer (Lvov), Rajmund Galon (Poznań) and Wanda Rewieńska (Vilnius), but this new development was torpedoed by the outbreak of the Second World War.

Looking back at the achievements of our predecessors during the period 1918-1939, we can conclude with satisfaction that they were significant. Their valuable theoretical and methodological studies survive to this day as sources cited both in Poland and abroad. Geographical research of that era was also very much of the applied kind. Geographers worked side by side with urban planners to lay the foundations for spatial and regional planning and tourism research was initiated in Krakow. Following their life stories we admire these wonderful people for their righteousness, courage and sacrifice for their country and for their beloved discipline - geography.

$$
\star \star \star *
$$

On 1 September 1939, German troops invaded Poland starting the Second World War that would continue for six long years. On 17th September, Soviet troops crossed the eastern Polish border, as Josef Stalin joined in with Adolf Hitler in his murderous plan to destroy Poland. In October, the Germans established the General Government (Generalgouvernement für die besetzten polnischen Gebiete, $G G$ ) in a section of occupied Poland with its capital in Krakow. Hans Frank was appointed head of the GG; his office was in the University of Science and Technology and residence at the Wawel Royal Castle.

Many Polish geographers were imprisoned in German POW camps (oflags and stalags). Soldier-geographers who fell into Soviet hands were mostly deported deep into the Soviet territory, or ended up in POW camps (where they would mostly be murdered).

Very soon, the German invaders started targeting Polish intelligentsia, especially in the area of culture, academia and education. Geography was selected among the disciplines regarded as particularly dangerous for the Third Reich.

During the period 1939-1945, numerous geographers sacrificed their lives hacked to death in concentration camps, shot by the Germans or their satellites, killed in the Warsaw Uprising or murdered by the Soviets at Katyń. Geographers also died from hard wartime living conditions, many fell during the defence of Poland in 1939 and on many fronts, including in the underground.

The war did not, however, stop Polish geography activity entirely. Naturally, its scope had to be severely limited, if only through the refusal to give Poles access to academic libraries. In concentration camps and other places 
of imprisonment and persecution some geographers carried on working on their books while others offered lectures, sometimes for hundreds of inmates. They fully realised that if discovered they faced certain death. Nevertheless, within $G G$, underground universities and secondary schools continued operating for the entire period of the occupation.

On 14 October 1939 the Gestapo arrested Stanisław Pawłowski in Poznań. He was charged with purported anti-German content in one of his public interventions earlier in June. The Germans also accused him of responsibility for the publishing of the Atlas nazw geograficznych Słowiańszczyzny Zachodniej (Atlas of geographic names of the Western Slavs) by Stanisław Kozierowski by the Institute of Geography of the Poznań University and his speech Geografia a obronność państwa (Geography and the defence of the state), which he deliverd in Krakow during the 7th Meeting of Geography Teachers on 28 May 1939. Stanisław Pawłowski was placed in a prison at Młyńska Street, from where he was transferred in December to Fort VII in Poznań, the first German concentration camp on Polish territory. He gave lectures to his fellow inmates until his execution by shooting around 3 p.m. on 6 January 1940. He was an eminent geographer active in geomorphology, human geography, political geography, regional geography and methods in teaching geography. Highly respected internationally he was the founder and long-time head of the department of geography in Poznań, member of the Polish Academy of Arts and Sciences, Rector of Poznań University, Head of the Geographical Society in Poznan and Vice-President of the International Geographical Union (appointed in 1938).

On 6 November 1939, the Germans staged Sonderaktion Krakau, the first act of their collective targeting of the Polish intelligentsia. At the order of the Gestapo the Rector of the Jagiellonian University, Tadeusz Lehr-Spławiński, invited professors to a lecture on the views of the Third Reich and National Socialism on science and higher education. The lecture was to be delivered by SS-Sturmbannführer Bruno Müller. The Rector believed that the lecture would provide the final approval of the occupying authorities for the opening of the University. Nearly all professors of the Jagiellonian University and many lower ranking academics, including from the University of Science and Technology, arrived in Collegium Novum. This however, was a trap set by the Germans. In a short speech Müller said, among other things: "Gentlemen, I brought you here to tell you that Krakow University has always been a centre for anti-German sentiments and has been educating young people in this unsympathetic spirit (...). For this reason you will be arrested and sent to a camp". Among the 183 professors rounded up were the following geographers: Jerzy Smoleński, Wiktor Ormicki, Stanisław Leszczycki, Stanisław Korbel (all from the Jagiellonian University) and Walenty Winid (College of Commerce).

The news of the imprisonment of the Krakow professors resounded around the world. It was carried by the world's largest newspapers and weeklies. Protests involving numerous intellectuals were staged in several neutral countries, including the USA, Sweden, Switzerland, Spain and Yugoslavia, Hungarians and Italians, German allies, were particularly active in efforts aimed at freeing those arrested. They even succeeded in convincing none less than Benito Mussolini himself to intervene. The Vatican also made an intervention and Pope Pius XII received the list of those imprisoned. Isolated protests came even from German scholars.

The professors were transferred from Krakow to a prison in Wrocław. There they initiated a series of talks that were held in the evenings, when the lights were out. The lecturers included geographers: Wiktor Ormicki ("Italian colonisation in Libya", "The problem of internal colonisation in Poland") and Stanisław Leszczycki ("Regional planning").

The group was then transferred to the Sachsenhausen concentration camp where, despite the inhuman conditions of everyday life, the professors continued with scientific 
talks. They called this the 'Open Camp University' and by February 1940 they had delivered nearly 300 lectures. Geographers active in this effort included Wiktor Ormicki, Stanisław Leszczycki, Walenty Winid and Jerzy Smoleński. On 5 January, Jerzy Smoleński succumbed to debilitation and sickness.

At this point, the Germans, who still reckoned with international opinion, decided to free some of the prisoners from Sachsenhausen. On 8 February 1940, 102 prisoners who were 40 or more years old (including Stanisław Korbel and Walenty Winid) left the camp. Before they were free to leave, they had to sign a statement that they would not actively pursue their profession. The remaining professors were transferred to other camps, including Dachau (on 4 March 1940, including Stanisław Leszczycki and Wiktor Ormicki) and some of them were set free at a later date.

Smoleński's death resonated around the world. On 26 January 1940, BBC Radio reported: "The well known Polish geologist and geographer George Smoleński died in a German concentration camp. He fell victim of the German bestial violence. Professor Smoleński (...), author of many scientific publications, was 60 years old." (Buszko \& Paczyńska 1995). The British, Canadian and American press carried obituaries, which highlighted his contribution to the development of Polish and international geography.

Poland lost an eminent geographer, one of the world's best geomorphologists, an eminent expert on European demography and one of the founders of the Polish school of political geography. He had been the long-serving Head of the Institute of Geography of the Jagiellonian University of Krakow, member of the Polish Academy of Arts and Sciences, Secretary General of the Polish National Geographic Committee and the Chairman of the League of Nations' Demographic Commission and of the Krakow Branch of the Polish Geographical Society (PTG). His whole life was characterised by truthfulness and incredible fortitude. After his imprisonment, he received an offer of freedom from the Germans in exchange for signing a declaration eschewing political activity and joining the German Ostinstitut, but he categorically refused to do this. Interrogated by the Germans, Wiktor Ormicki admitted to his Jewishness (his family bore the name Nussbaum until 1924, but had long been converted to Christianity). His fate was sealed, as he was transferred from Sachsenhausen first to Dachau and then to Mauthausen-Gusen (1940). Until his very last moments, Ormicki continued his scientific and educational work. In the extreme conditions of a penal company he wrote two large volumes: Problems of Population of the Globe and Problems of the Population of Desert Areas and of Water Supply to their Communities. We only know about these volumes from his fellow inmates, who would register to have an opportunity to read them. The manuscripts were destroyed on the day before the liberation of the camp in 1945. Wiktor Ormicki gave lectures for audiences of up to 200 people. Throughout the camp imprisonment he manifested an unbroken spirit and courage despite the awareness of the death that awaited him. The German perfidiousness had many faces, including the choice they offered him: death by drowning or hanging. He chose the latter.

On 17 September 1941, as he went to meet his fate, he spoke these wonderful words: "I know why they call for me (...). Yet, I go calmly. I go with that deep conviction that I do not die in vain; that it is all for Poland" (Jackowski 2011).

They murdered an eminent geographer, one of the founders of Polish regionalism and Polish human geography; the most eminent of Polish geographers of the young generation at the time. In late June 1939, a procedure had been initiated for his professorship.

Professor Walenty Winid died in Auschwitz on 19 January 1945. For many years based in Poznań, he moved to Krakow where he was offered the position of the head of the Department of Geography at the College of Commerce and also received the postdoctoral degree of docent at the Jagiellonian University. Professor Winid was the precursor of quantitative methods in geography 
and cartography and was active in American studies. Freed from Sachsenhausen in 1940, he became very active in research and teaching secret courses and was arrested again by the Germans in 1943.

Wanda Rewieńska-Pawełkowa, a geographer of the young generation and a member of Brownies, was executed by Lithuanian collaborators of the Germans at Ponary (a site of mass executions throughout the Second World War). After being captured she knew what awaited her, but she went around giving words of consolation and support to her fellow female prisoners till the very end. Wanda Rewieńska-Pawełkowa was already an eminent human geographer at the Stefan Batory University in Vilnius and just before the outbreak of the war she had initiated a procedure to receive habilitation at the Jagiellonian University.

On 1 September 1944, professor Stanisław Lencewicz with his wife Maria were among a crowd of people rounded up by Germans to be driven away from Warsaw in the middle of the city's uprising. The column of people were escorted by a Ukrainian SS formation. The soldiers were drunk and cruel. Lencewicz stood up in defence of a young woman the soldiers were tring to rape. In revenge they took the Lencewicz couple to the nearest gateway and shot them dead. Death took one of the most eminent Polish geographers, founder of geography in Warsaw and its longtime head, member of the Warsaw Scientific Society, and a physical geographer highly respected internationally.

Are the stands taken by our predecessors not a cause to be proud?

The early post-war period was very hard, particularly until 1956, and to many, such as those charged in political trials, it was also a tragic period. However, all worked towards one overreaching goal: to rebuild geography and to remain true to the fundamental research objective of relations between humans and their environment even in the new socio-political circumstances. Despite many pressures geographers did not give in to the influences of the communist doctrine and attempted to always serve the truth. This too can be a reason for our satisfaction. Indeed, our community proved to be capable of rising above the temporary political climes and while making great achievements in theory and methodology targeted ground work to ensure an unbiased approach to geography and to educate a generation of talented successors.

The period between 1945 and 1952 involved a series of important events that had been initiated in the late 1930s, such as nearly all 'habilitation' procedures and doctoral studies. This tough period involved rebuilding universities from the ruins, wrestling with the the daily realities, gradually building new organisational structures and making plans for the advancement of scientific research. The prewar units of geography at universities rallied to rebuild their structures while units created in the cities newly acquired by Poland in the west were populated by staff from cities lost in the east. Geographers from the Jan Kazimierz University in Lvov flocked primarily to Wrocław and those from the Stefan Batory University in Vilnius went to Toruń. There was a mixed team from both Lvov and Vilnius starting a geography department in Lublin. This was also a time, when the variety of prewar geographical societies and organisations were fused together. Geographers were also greatly involved in spatial and regional planning in war-ravaged Poland. The first academic textbooks began appearing virtually immediately after the end of the war, initially in very modest form and sometimes just typed manuscripts that circulated in a limited number of copies. Often the authors funded the print runs. Cartographic publishing houses sprang up despite the installation of the new regime's censorship machine.

This was also a dramatic time when the communist authorities rolled out violence which did not spare the academic community, including geography. The first geographer, Stanisława Zajchowska, was put on political trial in Lublin in late 1944, i.e. nearly immediately after the capture of the city by the Red 
Army. After the war, political restrictions affected many other geographers. Some of them met their death, such as Professor Stanisław Gorzuchowski, who died in jail in 1948. The officer-geographers from the Wojskowy Instytut Geograficzny (Geographic-Military Institute, WIG), the Polish Ministry of Defence's cartographic unit, faced a particularly bleak period. After the core of the staff had been murdered by the Soviets in Katyń in 1940, the new regime fabricated a 'spying scandal' leading to the arrest of WIG's head Teodor Naumienko and the disbanding of the organisation in 1949.

After 1952, the structures in academia devoted to geographical topics continued to expand and as they gained in recognition some universities decided to devote entire faculties to either geography or earth sciences. After the momentous year 1956, when the communist regime loosened its grip across the Eastern bloc, Polish geographers began organising polar expeditions, mainly to Spitsbergen, where some universities established their research stations.

In the 1980s the quality of geography facilities began to gradually improve and today most universities have a well-equipped teaching and laboratory base, often located on campuses, which have replaced dispersed city buildings.

In 1953, the Polish Academy of Sciences opened its Institute of Geography (now Stanisław Leszczycki Institute of Geography and Spatial Organization) in Warsaw, thus breaking the traditional monopoly of universities on geographical research. The new unit soon became the leading geography establishment in Poland, as it coordinated domestic research and kept extensive contacts with international partners.

In 1968, Stanisław Leszczycki was elected President of the International Geographical Union for a four-year term that marked the highest point in the history of Polish geography.

Geographers explored an increasingly diverse range of research topics. New areas included soil studies, tourism research (a return to a very accomplished area before the war) and the introduction of GIS tools. The first papers were published on behavioural and social geography and new subdisciplines, such as geography of religion, were established. Geographical publications proliferated, including in the area of theory and methodology, and new periodicals were launched.

Looking back at post-war developments it becomes very clear how lingering were the effects of the two conferences of the deep-communist era at Osieczna (1955) and Jabłonna (1966). Polish geography was facing a crisis and geographers of the younger generation were trying to address it at the 2 nd and 3rd Congresses of Polish Science (1973, 1986). Although the disciplines affected were primarily economic and regional geography the indirect influence extended to physical geography as well. The first partly successful efforts to "put things right" were made at and after the convergence at Rydzyna (1983).

Against these odds Polish geography developed quite rapidly, which it owed primarily to contacts, both official and private, with international partners, mainly in the west. It is quite reassuring that a clear majority of geographers resisted political pressures and conducted their research in accordance with Cicero's motto, "Our thoughts are free". The communist authorities responded with constant intervention through censorship of manuscripts submitted to print. The situation improved radically after the transformation of 1989.

In the on-going debate on the essence of geography many of its participants, especially young-generation geographers, are not fully aware of our illustrious traditions. The origins of the debate go back to antiquity and this accelerated in the times of Alexander von Humboldt and Karl Ritter.

For some time, the state of awareness of Polish geography in the general public has been worrying. Indeed, geography is being generally equated to memorialised encyclopaedic knowledge. It is being limited to details, such as the names of mountain ranges, names and heights of mountain 
peaks, lengths of rivers, population and industrial output statistics. This is the idea of geography many people have today, well into the 21 st century. Worrisome as it may be, nothing happens without a reason and this state of awareness is a result of the quality of education at school and college level and of inept popularisation of knowledge, such as in TV geography quizzes. Supporters of this idea of geography might be very surprised to learn that such a 'geography of details' was criticised by one of the fathers of the Institute of Geography at the Jagiellonian University, Ludomir Sawicki, one hundred years ago. In 1909, he warned that: "the dry recounting of peaks, rivers, cities and populations (...) only placed a burden on the memory, but failed to engage the mind". He also highlighted that geography "is attempting to establish a strict causal and developmental link between individual phenomena on the surface of the earth. In this way from a chaotic and varied material geography builds a single whole. (...) I would like to refer to geography as a kind of a philosophy of natural sciences and humanist arts, which (...) builds a synthetic and free standing edifice from the material passed on to it by auxiliary disciplines using its own method (...) and in a deluge of phenomena seeks order, system and a causal and developmental link" (Sawicki 1909). He often stressed that "geographic disciplines constitute a momentous factor in the cultural and social development of Poland"4.

Sadly, geography has been gradually losing the status of a discipline perceived as necessary for a 'normal' functioning of the state and educating society. Perhaps it is right to quote the same author again here, when he said "The idea is spreading through society that a modern citizen should rest his beliefs about his Fatherland and the world on the strong foundations of that science [that is geography] which strives to encompass nature and man in the multitude of his

\footnotetext{
${ }^{4}$ Excerpt from a speech by L. Sawicki delivered during the Congress of Polish Geographers in Krakow, 9-11 May, 1922.
}

facets with an unbiased look and to build on a comprehensive knowledge an edifice of harmonious knowledge about the earth" (Sawicki 1928).

As early as in the 19th century, relations between the environment and the various aspects of human activity began making their way into mainstream geography. It soon turned out that geography was the only discipline of knowledge that, due to its scientific apparatus and research methods, was in a position to link various processes not just with the natural environment, but also to correctly interpret them both spatially and socio-economically. It offers tools to produce spatial studies based on mutual links between the various elements of the environment and human activity, while at a more basic level it helps to obtain an informed view of one's country and the world. These advantages were particularly valued during the inter-war period when geography enjoyed much respect with the state authorities, but was also very much present in the minds of the people. Sawicki wrote: "The discipline of geography penetrates all aspects of human work. Just as there is no subject at school that would not link strictly, or even necessarily, with geography, so in daily life there is no activity in which geographical information, reasoning and methods would not offer much support and advantage. Indeed, this discipline supports itself in a natural way on highly varied material, has a highly synthetic nature and in every one of its sub-disciplines comes into contact with the subjects that are the most important both at school and in life: with the inanimate earth, with animate nature and with human beings. Here is the source of the entire educational and practical meaning of geography" (Sawicki 1918). Foundations for a geography so defined were laid by our illustrious predecessors, their students and the students of their students. New links are still being added onto this chain of eminent geographers even if they may not yet be known to the general public.

Stanisław Pawłowski wrote in the 1930s, "Geography is walking in the first row of those 
disciplines that serve the state. (...) Geography is becoming a serious lever in public education at school and at the same time it tends to be regarded as the discipline, on which rest (...) all efforts towards the development and consolidation of economic and political life" (Pawłowski 1934). He continued, "If history is regarded as 'the tutor of life' then geography ought to be referred to as the 'conductor of life'. (...) In all measures taken about the internal and external life of states and nations the services of geography cannot be left unused. (...) Everyone needs geography. (...) He who forgets about geography in moments crucial for the nation and the state may expose public matters to severe failures and painful losses." He observed: "Every enterprising human, every society, no matter how small and weak, and every state needs geography. (...) Indeed, geography expressed in the knowledge of the world, in a set of information about one's own country and about neighbouring countries, a geography probing the essence of relations between geographic conditions and factors and humanity, such a geography cannot but direct human attention and human will towards a direction that is the best for this humanity. In this sense geography is a useful and therefore also a practical discipline and not just theoretical" (Pawłowski 1939).

Judging by the state of public opinion today it has been all but forgotten that it was geography, alongside history, which was this discipline of knowledge that has always taught and consolidated in Poles their sense of patriotism. This was true for centuries and this is the role of geography I would like to see also in the 21st century. The writings of the foremost Polish geographers confirm that a majority of their ideas and beliefs about the role of geography in the life of the state and of society have lost nothing of their topicality despite the years that have past. This is also true about their considerations on the significance of geography in the development of patriotism, especially in young people. Pawłowski regarded geography as "an important subject in education in the spirit of the state", playing a similar role as the mother tongue (Pawłowski 1932b). He justified his statements with the following conclusions:

1) Geography inherently deals with the state.

2) It is one of the goals of official education to learn about the spiritual and material culture of the nation. Geography as a school subject fulfils that role by promoting learning about the material culture and arouses staterelated feelings.

3) Geography educates in the spirit of the state both intellectually and emotionally. In this case geography's role is particularly important, because:

a) Geography offers concrete information about the geographic components of the state;

b) Only geography is called to explain the relationship between the human being and the earth, and in this case - the state;

c) Geography teaches about other states, which helps compare one's own and these states.

4) Geography arouses a love for the land of the fathers. The significance of geography in this respect is 'unquestioned'. One cannot understand Poland without knowledge of the geography of other European states and beyond: "The future citizen of Poland must have a sense of being also a citizen of the world, since Poland too is speaking with an ever stronger voice about global issues" (Pawłowski 1932b).

This message of Polish geographers is of a timeless quality and without much modification may be adapted to the contemporary situation taking globalisation into account. Indeed, it involves building patriotic attitudes around one's home community, the country and even the world.

Many of our geographers paid for their patriotism with their lives or with crushing hardship at the hands of Nazi and Soviet terror. The martyrdom of our predecessors must not be in vain!

$$
\star \star \star *
$$

One can develop an interest in our discipline at an early age and then find arguments 
to consolidate this interest at a later stage. Interestingly, the first statement to the press by Professor Władysław Bartoszew$\mathrm{ski}^{5}$, a non-geographer, was about geography. In 1934, at the age of 12, this is what he replied to a reporter's question, whom would you like to become and why? "I'd like to become a geographer, because I'm interested in and like geography, from which we learn about our Fatherland, its provinces, inhabitants, the climate, about foreign countries, cities, mountains, rivers, etc." (Komar \& Bartoszewski 2006).

In 1951, at a time when Stalinism was approaching its peak in Poland, I myself took a decision to study geography in the future. As often happens, the inspiration came from an unexpected direction. I was in my secondary school and our library received an instruction to destroy all books published during the 'bourgeoisie period', which meant before 1939. Our head teacher, a very wise man, summoned trusted pupils and asked us to take any books that interested us. Among many others, I took Dzieje wypraw polarnych (The story of Polar Expeditions) by a very well-known Polish polar researcher, Antoni Bolesław Dobrowolski. I read that book in one night and knew I would become a geographer. Many years later, I am certain that it was the right choice.

My close contact with geography goes back to 1954, when I enrolled in the Institute of Geography of the Jagiellonian University. Geography became one of the loves of my life, which only grew mature with experience, successes and failures. We are both old friends who, due to our age, demand from each other both respect and assistance. After years of observation, I come to the conclusion

5 Władysław Bartoszewski (born 1922), Polish politician, journalist, author, social activist and historian. Inmate of Auschwitz concentration camp. Soldier of the Polish underground Home Army and participant in the Warsaw Uprising of 1944. Political prisoner in Poland between 1946 and 1954. Twice Foreign Minister of Poland (1995 and 2000-2001). Champion of Polish-Jewish and Polish-German reconciliation. Author of more than 50 books and 1500 press articles. that it is mostly my Lady Friend Geography who is the one in need of urgent help or even resuscitation. Over these last decades, many experiments, often unjustified, were performed on its body without anaesthesia. The poor Lady Friend took it all good-naturedly and did not lose hope that one day these brutal attempts would stop. For 60 years, I had an opportunity to see how my Lady Friend Geography was being cut from its roots by various 'trendy' ideas, which often turned out to be ephemeral.

$$
\star \star \star
$$

I must make one thing clear here to avoid any misunderstanding. I am very much in favour of exploring new fields of research, because this is how scientific progress is achieved, and geography is no exception. Indeed, many new ideas floated in the international literature truly deserve the continued attention of geographers, including myself, and this is what I recommend to my students. What I am concerned about is a fascination with the 'novel' that tends to blind us to important and inspiring studies published in the past, including before the Second World War. This is sadder still as the names of our predecessors can be found more often in international than in domestic publications.

The advancing disintegration of geography has led to a proliferation of narrow new fields that operate in separation from others, often without any need for joint projects with their other 'sisters'. This fragmentation is also visible in teaching where it is increasingly difficult to find a lecturer ready and willing to deliver courses with a broad scope, such as in general physical or human geography. In his time, Stanisław Leszczycki attempted to prevent this situation occurring when he proposed replacing the term 'geography' with 'geographic sciences' intended to encompass all subdisciplines and specialisations that had grown out of the common root (Leszczycki 1962). This move has failed to solve the problem of disintegration and the process continues, mostly as 'an internal disintegration of geography' (Liszewski 2004). The process accelerated in the late 1970s as the generation of our 
Masters began to retire. The younger generation does not find disintegration to be a threat to geography at all.

The first evidence of concern with the adverse effects of specialised narrow fields had already appeared at the start of the 20th century. Wacław Nałkowski, for example, thought that only an approach encompassing all aspects of the picture ensures a quality result in geographical research. He referred to some studies by Albrecht Penck as examples of an adverse impact of narrow specialisation on the quality of the output. In these publications, according to Nałkowski, the physical geography part was 'state of the art', while the human geography part was "mostly dry, full of historical dates and statistics" (Nałkowski 1910). He went on to say that "by limiting oneself to a single subdivision of geography (...) a geographer risks going lame as he loses the dualist character of geography". One has similar thoughts when reading some contemporary studies. History tends to repeat itself, but this should not serve as an excuse for not responding when it does.

Elsewhere, the classics of geographical research are being revisited and reread. Great names of the past can now be found cited in nearly all newly published studies. Very recently, a selection of geography papers spanning the last 200 years was published in France (Robic et al. 2011). An anthology of major studies on human geography was published in the UK and USA in the form of an academic textbook (Agnew et al. 1996). The Germans published an anthology of old studies on the geography of tourism (Hohmeister \& Steinecke 1984). In Poland this type of promotion of our own traditions does not seem worthy of serious effort. In an isolated attempt Witold Wilczyński (2012) published a mini anthology of this type on the occasion of the imminent 2014 Regional IGU Conference in Krakow. Years ago, Stanisław Leszczycki (1975) published a selection of his own studies on applied geography and there is a trickle of biographical publications that contain excerpts from the researcher's studies.
We cannot expect 'the world' to appreciate us if we fail to respect ourselves. Indeed, many studies published during the inter-war period remain current to this day, but they are read extremely rarely, let alone cited in contemporary publications, especially by young geographers. I shall leave that without comment.

Often one has the impression that we are ashamed of the word 'geography', a word that for us, geographers, ought to be a synonym of the 'mother science'. 'Geography' is being replaced with various other terms the adverse effect of which has been flagged up in many debates in Poland (Bański 2010; Lisowski 2004; Liszewski 2004). This substitution phenomenon has been frequent, especially in naming departments and teaching courses. No field has been affected more than the broadly understood human geography where the word 'geography' has been replaced by such terms, as 'regional development', 'tourist industry', 'tourism', 'spatial economy', 'regional studies', 'political studies', 'regional analysis', 'food economy', 'development of the environment', etc. Physical geography has not been free of the effect, but it has occurred on a much smaller scale. Here the names of departments are linked to the various sub-disciplines. We have been observing the spread of this trend and a similar situation can be found in the Anglo-Saxon countries (Lisowski 2004). This strange situation is exacerbated by certain actions suggesting that some geographers active in the field of physical geography do not see a need to integrate with colleagues from other disciplines. Examples of such actions include the 'spinning-off' of geomorphology, landscape ecology and climatology, from the Polish Geographical Society with each establishing their own associations, which are partly competing with the PTG. I am becoming increasingly convinced that geography as such is coming to the edge of self-destruction. There will be geomorphologists, climatologists, hydrologists, planners and tourism scientists. But there will be no geographers. Other disciplines, such as history and physics, face no such processes. This 
may be a reason why their standing in the Polish scientific landscape and in the public opinion is so high.

This disintegration may have led to the consolidation of focus profiles in some geography centres, but has also sent a clear signal to public at large that the terms 'geography' and 'geographer' were obsolete. The traditional terminology has been gradually replaced by more 'market-oriented' nomenclature. We should not therefore be surprised that our profession has been losing its authority and the subject is being squeezed out from school curricula.

We must admit that much of the observed decline in the general appeal of geography and its diminishing stature in the eyes of the Polish society, including among decisionmaking circles holding funding for science and higher education, has been our very own fault. We failed to stand up and protest when amateurs were taking our legitimate place by publishing quasi-scientific papers with the word 'geography' slapped in the title. Although shrinking in stature, however, our community has managed to maintain its identity, which was possible mainly thanks to the top-notch quality of our research. In this way we were able to save Polish geography from pressures to accept mediocre research and imposters with scientific titles and posts.

While research in geography offered original and innovative methodology, our community has failed to ensure sufficient promotion of its significance. Recently, this has been changing and geography establishments are receiving more and more offers of cooperation from local, central and professional authorities.

$$
\star \star \star
$$

Action is needed if the current status of geography is to change. The Polish Geographical Society (PTG) decided that the first priority would be for geography to regain its stature in public opinion. This goal should be helped by the Regional Conference of the International Geographical Union to be held in Krakow between 18 and 22 August 2014. In 2009, PTG Chairman, Professor Jerzy Bański, proposed Krakow's candidacy to the IGU Executive Committee which then approved it at a meeting in Moscow. PTG is a member of the Steering Committee preparing the event and one of the main organisers. It is also playing a very large part in the preparation of the monumental exhibition "The Development of Geographical Thought in Poland", the first of its kind in Poland. This will be the second large scientific event organised by the International Geographical Union in Poland after the 1934 Congress. It will give us an opportunity to both reflect on past achievements and outline the future development of Polish geography.

The reinstatement of geography to its rightful place in the social and national structures was also adopted as first priority in the celebration of the 100th anniversary of the Polish Geographical Society in 2018. This anniversary ought to become a festival for all Polish geographers. Over these 100 years, Polish geography and Polish geographers kept working on building social awareness of the importance of our discipline for economic, social and cultural life. Our predecessors worked on this task regardless of changing fortunes in the history of Poland. Geography was one of the main links in the patriotic upbringing of many generations of Polish youth. A sad confirmation of this is the list of losses to Polish geography during the Second World War. Numerous geographers were involved in resistance against the German and Soviet aggressors and often paid the highest price, the loss of their life. When preparing the materials necessary for our efforts, I reached for the thoughts of our predecessors from as much as even one hundred years ago. The world has seen much change during that time, including the ravages of the Second World War, two totalitarian systems, Nazism and communism, the explosion of technological progress; yet the writings of these Great Geographers have lost nothing of their relevance. Simply, for them too, geography was a Great Love!

I hope that the two special events we are awaiting in the years to come will help Polish geography regain the place it deserves in the minds of the general public. 
Having written these modest considerations, I now want to urge a rapid and radical change in the perception of what geography is. While doing this, let us not be afraid of resting on the achievements of our predecessors. Let us remember that it is thanks to them that we are in a position to cultivate our beloved discipline.

In conclusion, I return to the question of what is geography? Speaking in plain language it is a wonderful scientific discipline with a potential to fascinate researchers to the point where they devote their entire lives to it. It inspires us to investigate contemporary phenomena, but also leads us to looking for their origin in the past. Only geography is capable of teaching us how to 'read' the surrounding landscape through the interpretation of its change over the course of history. The map always has been the basic research tool of the geographer. Providing a snapshot of the space surrounding us it helps us to better understand the relationship between the natural environment and human activity. Only geography helps us understand the 'spirit' of the natural environment and cultural landscapes. This creates a potential for societies to develop a modern type of patriotism which rules out all nationalisms. Such contemporary patriotism, based on geographical foundations, can be both regional and global. Patriotism of this type involves everything that is common and rejects mutual resentments that often go way back to a distant past. These unique qualities have made me fall in love with geography and I have always been proud to be a geographer.

All that I have enumerated above fits very well with the classic definition of 'geography'. We wrote above that this definition changed very often, depending on developments in science as a whole and natural sciences in particular. Some of these proposed changes must have been rather unusual if they had the potential to unsettle such a calm and composed person as Stanisław Pawłowski. Perhaps intending to curtail one such non-constructive discussion, he wrote:
"Geography as a discipline has its own character. Hence, to the question 'What is geography?' we may answer 'Geography is geography'" (Pawłowski 1932a). This is certainly not a standard 'professor's' answer and what we may be seeing here is a man irritated by idle discussion, especially considering that elsewhere he offered a very interesting attempt to outline the qualities of geography as a kind of a response to the question quoted above. The main points of the author's argument are:

1) "As a synthesising discipline, geography captures the whole without omitting details."

2) "Geography teaches about mass phenomena."

3) "Geography is non-partisan. It speaks about matters of the entire state that are equally important to each citizen, rather than to specific social groups. Being non-partisan and unbiased it eradicates differences and resentments between provinces and teaches us to love and understand all parts and lands of Poland."

4) "Geography is above national divisions within the state. It educates all national groups equally and develops in them a sense of community and unity within the state."

5) "Geography educates the future Polish citizen and soldier equipping him with information useful in life and teaching him orientation within and outside Poland."

6) "Geography teaches us how to love the real and unchanging values of statehood, values that are beyond question and raise no doubts" (Pawłowski 1932b).

It seems to me that these thoughts could be used in drafting a contemporary definition of geography, one that would be firmly planted in the 21st century with its trends to globalisation. Work on such a new definition should be undertaken as soon as possible and be based on a wide-ranging international debate.

In the final word of my considerations I would like to offer these two questions: Are we, in the second decade of the 21st century, capable of objective thinking about the essence of Polish geography? Will we undertake efforts to respect the treasure 
of knowledge created by our predecessors and not expose it to confusion linked with a drive to a global disintegration of what they

\section{References}

Agnew J.A., Livingstone D.J., Rogers A. (eds.), 1996. Human geography: Essential anthology. Oxford: Blackwell.

BAŃSKI J., 2010. Stan krytyczny polskiej geografii - krytyka stanu. Przegląd Geograficzny, vol. 82, no. 3, pp. 319-333.

Buszko J., PAczyńska I., 1995. Podstępne uwięzienie profesorów Uniwersytetu Jagiellońskiego i Akademii Górniczej (6 XI 1939 r.). Dokumenty. Kraków: Uniwersytet Jagielloński.

Hofmeister B., Steinecke A. (eds.), 1984. Geographie des Freizeit-und Fremdenverkehrs. Darmstadt: Wissenschaftliche Buchegesellschaft.

IzMAlŁow B., 2004. Historia geografii polskiej [in:] A. Jackowski (ed.), Encyklopedia szkolna. Geografia, Kraków: Wydawnictwo Zielona Sowa.

JACKOWSKI A. (ed.), 2011. Do końca wierny Polsce i Geografii. Wiktor Rudolf Ormicki (1898-1941). Kraków: Instytut Geografii i Gospodarki Przestrzennej Uniwersytetu Jagiellońskiego.

Komar M., BartoszeWski W., 2006. Skqd pan jest? Wywiad rzeka. Warszawa: Świat Książki.

LESZCZYCKI S., 1962. Rozwój myśli geograficznej [in:] A. Malicki (ed.), Geografia Powszechna, vol. 1, Warszawa: Państwowe Wydawnictwo Naukowe, pp. 20-56.

LESZCZYCKI S., 1975. Geografia jako nauka i wiedza stosowana. Warszawa: Państwowe Wydawnictwo Naukowe.

LISOWski A., 2004. Refleksje nad rozwojem geografii: od problemu dezintegracji do problemu tożsamości dyscypliny [in:] A. Jackowski (ed.), Geografia u progu XXI wieku. Krakow: Komitet Nauk Geograficznych PAN, Instytut Geografii i Gospodarki Przestrzennej. Uniwersytet Jagielloński, pp. 77-85.

LIsZEWSKI S., 2004. Stan dyskusji polskich geografów na temat jedności i zakresu pojęciowego regarded as a unity? These questions may seem banal, but the answers are by no means clear. And they certainly require debate.

wspótczesnej geografii (na poczatku XXI wieku) [in:] A. Jackowski (ed.), Geografia u progu XXI wieku. Krakow: Komitet Nauk Geograficznych PAN, Instytut Geografii i Gospodarki Przestrzennej. Uniwersytet Jagielloński, pp. 11-26.

NAŁKOWSKI W., 1910. Krajoznawstwo i jego stosunek do geografii. Warszawa: Druk Piotra Laskauera i S-ki.

PAwŁowski S., 1932a. O przyrodniczych podstawach geografii i o jej istocie. Kosmos. Seria A. Rozprawy, vol. 57, no. 1-4, pp. 279-296.

PaWŁowski S., 1932b. Państwowo-wychowawcze znaczenie geografii. Oświata i Wychowanie, vol. 4, pp. 25-37.

PaWŁowskı S., 1934. Na zamknięcie Międzynarodowego Kongresu Geograficznego w Polsce. Gazeta Polska, vol. 6, no. 241.

PAWŁowski S., 1939. Rola geografii wżyciu narodów. Czasopismo Geograficzne, vol. 17, no. 2, pp. 1-2.

Robie M.-C., Tissier J.-L., Pinchemel P., 2011. Deux siècles de géographie française. Une anthologie. Collection CTHS géographie, 8. Paris: Comités des travaux historiques et scientifiques.

SAWICKI L., 1909. Geografia a krajoznawstwo. Odczyt wygłoszony na posiedzeniu Towarzystwa Krajoznawczego w Warszawie, dnia 10 listopada 1909 roku. Wszechświat, vol. 28, no. 47, pp. 737-741.

SAWICKI L., 1918. Zakłady państwowe a geografia ojczysta. Przegląd Geograficzny, vol. 1, no. 1-2, pp. 5-17.

SAWICKI L., 1928. Przemówienie inaugurujące I Zjazd Koleżeński Geografów Krakowskich [in:] S. Korble (ed.), Pamiętnik I Zjazdu Koleżeńskiego Geografów Krakowskich odbytego w dniach 2-4 lutego 1928 r. w Krakowie. Krakow: Komitet Organizacyjny IZKGK, pp. 38-39.

WILCZYŃSKI W. (ed.), 2012. A source book of the Polish classical geography. Krakow: Wydawnictwo Księży Sercanów Dehon. 
http://rcin.org.pl 